Proceedings

\title{
Immediate and Delayed Mortality of Tribolium confusum Adults and Larvae on Concrete Surfaces Treated with Chlorantraniliprole ${ }^{+}$
}

\author{
Nickolas G. Kavallieratos ${ }^{1}$, Maria C. Boukouvala ${ }^{1,}$ *, Erifili P. Nika ${ }^{1}$ \\ 1 Laboratory of Agricultural Zoology and Entomology, Department of Crop Science, Agricultural \\ University of Athens, 75 Iera Odos str., 11855, Athens, Attica, Greece nick_kaval@aua.gr (N.G.K.); \\ mbouk@aua.gr (M.C.B.) erifilinika@aua.gr (E.P.N.) \\ * Correspondence: mbouk@aua.gr; Tel.: +30-2105294569 \\ † Presented at the 1st International Electronic Conference on Entomology (IECE 2021), 1-15 July \\ 2021; Available online: https://iece.sciforum.net/.
}

Citation: Kavallieratos, N.G.; Boukouvala, M.C.; Nika, E.P. Immediate and delayed mortality of Tribolium confusum adults and larvae on concrete surfaces treated with

chlorantraniliprole, in Proceedings of the 1st International Electronic Conference on Entomology, 1-15 July 2021, MDPI: Basel, Switzerland, doi:10.3390/IECE-10362

Published: 30 June 2021

Publisher's Note: MDPI stays neutral with regard to jurisdictional claims in published maps and institutional affiliations.

Copyright: (C) 2021 by the authors. Submitted for possible open access publication under the terms and conditions of the Creative Commons Attribution (CC BY) license (http://creativecommons.org/licenses /by/4.0/).

\begin{abstract}
Adults and larvae of Tribolium confusum were exposed for 1, 2, 3, 4 and $5 \mathrm{~d}$ on concrete treated with chlorantraniliprole SC at four doses $(0.01,0.05,0.1$ and $0.5 \mathrm{mg}$ active ingredient $/ \mathrm{cm}^{2}$ ). Then, the adults and larvae alive were transferred on untreated concrete and delayed mortality was evaluated after $7 \mathrm{~d}$. Larval mortality ranged from 61.1 to $78.9 \%$ while adult mortality ranged between 40.0 and $70.0 \%$, after $5 \mathrm{~d}$. Delayed mortality was high for both life stages, reaching 97.2 and $100.0 \%$ for adults and larvae, respectively. To conclude with, chlorantraniliprole is an effective management tool against T. confusum on concrete surfaces.
\end{abstract}

Keywords: confused flour beetle; anthranilic diamide; efficacy; surface treatment

\section{Introduction}

The confused flour beetle, Tribolium confusum Jacquelin du Val (Coleoptera: Tenebrionidae), is considered one of the most serious pest of stored and processed grains worldwide [1, 2], infecting 138 different types of commodities (e.g., flours, bran, cereal and oil seeds, spices, and a broad spectrum of dry plant materials) [3]. It is also a serious insect pest in mills, as it can easily find refuges and food in cracks and crevices in milling facilities, as well as the ideal conditions for its growth and development [5]. However, management of this species is an important issue since it is tolerant to several insecticides, such as the pyrrole insecticide chlorfenapyr [6], or the members of spinosyn group, spinosad and spinetoram [7]. Moreover, T. confusum was found to be the least susceptible among the lesser grain borer, Rhyzopertha dominica (F.) (Coleoptera: Bostrychidae), and the rice weevil, Sitophilus oryzae (L.) (Coleoptera: Curculionidae), to three different formulations of diatomaceous earths [8].

Chlorantraniliprole, is a novel insecticide that belongs to the chemical group of anthranilic diamides $[9,10]$, which has low mammalian toxicity and can kill a wide range of insect pests without harming beneficial arthropods [11-14]. For instance, it is very effective for species of agricultural importance belonging to different orders, e.g. Coleoptera, Lepidoptera, Hemiptera, Diptera, Isoptera and Thysanoptera [15-21]. Furthermore, recent studies have shown the insecticidal activity of chlorantraniliprole for stored-product protection, either as grain protectant [22,23] or as surface treatment [24]. Thus, the objective of the present work was to examine the immediate and delayed mortality of chlorantraniliprole SC on concrete surface, against adults and larvae of T. confusum. 


\section{Materials and methods}

\subsection{Insect, commodity and Insecticidal Formulation}

The adults and larvae of T. confusum used in the bioassays are kept in the Laboratory of Agricultural Zoology and Entomology, Agricultural University of Athens, since 2014. The insects were initially collected from Greek storage facilities in 2003 and reared in wheat flour including $5 \%$ brewer's yeast $(\mathrm{w} / \mathrm{w})$ at $27^{\circ} \mathrm{C}$ and $60 \%$ relative humidity, in continuous darkness. Moreover, all adults of the tested species were 7 days old and larvae were 3rd - 4th instar [25]. Clean, without infestation, and pesticide-free white soft wheat flour (a variety mixture, made from the endosperm only) was used as food in the experiments. The concrete surface was treated with the formulation of chlorantraniliprole, Coragen ${ }^{\circledR}$ SC (suspension concentrate) with $200 \mathrm{~g} / \mathrm{L}$ active ingredient (a.i.), which was provided by Dupont (Halandri, Greece).

\subsection{Bioassays}

The concrete surface of individual dishes was sprayed with $1 \mathrm{ml}$ of an aqueous solution, as a fine mist, that contained the appropriate volume for each dose of chlorantraniliprole (i.e. 0.01, 0.05, 0.1 and $0.5 \mathrm{mg}$ a.i. $/ \mathrm{cm}^{2}$ ), using an AG-4 airbrush (Mecafer S.A., Valence, France). Then, $10 \mathrm{~T}$. confusum adults or larvae were placed on each sprayed dish, which contained $0.5 \mathrm{~g}$ white soft wheat flour. Before the beginning of the experiments, the moisture content of the flour was adjusted to $13.5 \pm 0.5 \%$ as determined by a calibrated moisture meter (mini GAC plus, Dickey-John Europe S.A.S., Colombes, France) either dried inside oven at $50{ }^{\circ} \mathrm{C}$ or hydrated with distilled water according to its initial moisture content [26, 27]. Then, it was sprinkled over the surface area of the concrete one day after spraying. An additional series of dishes were prepared and sprayed, as described above, with distilled water, and served as controls. Afterwards, all dishes were placed in incubators set at $25^{\circ} \mathrm{C}$ and $65 \%$ relative humidity and continuous darkness. Mortality was determined by prodding the insects gently with a brush to detect movement under an Olympus stereomicroscope (Olympus SZX9, Bacacos S.A., Athens, Greece) after 1, 2, 3, 4 and $5 \mathrm{~d}$ of exposure on the treated substrate. The brush was carefully washed after the examination of each dish. After the 5-days interval, the surviving adults or larvae were transferred to new dishes with untreated concrete surfaces, containing $0.5 \mathrm{~g}$ white soft wheat flour for 7 days more at the same conditions. After this period, the new dishes were opened and the number of dead adults or larvae was counted as described above.

\subsection{Data Analysis}

Immediate or delayed mortality of control was low $(<3 \%)$, so no correction was considered necessary.Data were analyzed separately for immediate and delayed mortality by following the repeated measures model [28]. All analyses were conducted using the JMP 14 software [29].

\section{Results}

\subsection{Immediate and delayed mortality of T. confusum adults}

Mortality was very low after 3 days of exposure in all tested doses, not exceeding $27.8 \%\left(0.5 \mathrm{mg}\right.$ a.i. $\left./ \mathrm{cm}^{2}\right)$ (Table 1$)$. After 4 days, mortality increased further, reaching $46.7 \%$, at 0.5 a.i. $/ \mathrm{cm}^{2}$, while at the rest doses it ranged between 27.8 and $33.3 \%$. One day later, chlorantraniliprole killed $70.0 \%$ of exposed adults at the highest dose and caused moderate mortality to the lower doses (i.e. $0.01,0.05$ and $0.1 \mathrm{mg}$ a.i. $/ \mathrm{cm}^{2}$ ),. Delayed mortality was high, even in the low doses, killing more than $86.5 \%$ of the survived adults (Table 2). 
Table 1. Mean immediate \pm SE mortality (\%) of T. confusum adults and larvae exposed on treated concrete with chlorantraniliprole $\mathrm{SC}$ at four doses $\left(0.01,0.05,0.1\right.$ and $0.5 \mathrm{mg}$ a.i. $\left./ \mathrm{cm}^{2}\right)$, for $1,2,3,4$ and 5 days.

\begin{tabular}{cccccc}
\hline & \multicolumn{5}{c}{ Adults } \\
\hline $\begin{array}{c}\text { Exposure } \\
\text { Dose }\end{array}$ & 1 day & 2 days & 3 days & 4 days & 5 days \\
$0.01 \mathrm{mg}$ a.i. $/ \mathrm{cm}^{2}$ & & & & \\
$0.05 \mathrm{mg}$ a.i. $/ \mathrm{cm}^{2}$ & $0.0 \pm 0.0$ & $0.0 \pm 0.0$ & $11.1 \pm 1.1$ & $27.8 \pm 1.5$ & $40.0 \pm 2.4$ \\
$0.1 \mathrm{mg}$ a.i. $/ \mathrm{cm}^{2}$ & $0.0 \pm 0.0$ & $0.0 \pm 0.0$ & $17.8 \pm 1.5$ & $30.0 \pm 2.9$ & $47.8 \pm 1.5$ \\
$0.5 \mathrm{mg}$ a.i. $/ \mathrm{cm}^{2}$ & $0.0 \pm 0.0$ & $6.7 \pm 1.7$ & $27.8 \pm 1.5$ & $46.7 \pm 2.9$ & $70.0 \pm 2.4$ \\
& & & Larvae & & \\
$0.01 \mathrm{mg}$ a.i. $/ \mathrm{cm}^{2}$ & $0.0 \pm 0.0$ & $5.6 \pm 2.4$ & $17.8 \pm 2.8$ & $33.3 \pm 1.7$ & $61.1 \pm 2.0$ \\
$0.05 \mathrm{mg}$ a.i. $/ \mathrm{cm}^{2}$ & $1.1 \pm 1.1$ & $7.8 \pm 2.2$ & $18.9 \pm 2.0$ & $34.4 \pm 1.8$ & $63.3 \pm 1.7$ \\
$0.1 \mathrm{mg}$ a.i. $/ \mathrm{cm}^{2}$ & $2.2 \pm 1.5$ & $12.2 \pm 2.8$ & $21.1 \pm 3.1$ & $38.9 \pm 2.0$ & $67.8 \pm 2.8$ \\
$0.5 \mathrm{mg}$ a.i. $/ \mathrm{cm}^{2}$ & $4.4 \pm 2.4$ & $18.9 \pm 3.1$ & $37.8 \pm 4.7$ & $53.3 \pm 3.7$ & $78.9 \pm 1.1$ \\
\hline
\end{tabular}

\subsection{Immediate and delayed mortality of $T$. confusum larvae}

After 2 days of exposure mortality was in very low levels, reaching $18.9 \%$ of the exposed larvae (Table 1). One day later, mortality increased further for all tested doses, ranging between 17.8 and $37.8 \%$. After 4 days of exposure, moderate $(53.3 \%)$ mortality was noted at $0.5 \mathrm{mg}$ a.i. $/ \mathrm{cm}^{2}$, while at doses between 0.01 and $0.1 \mathrm{mg}$ a.i. $/ \mathrm{cm}^{2}$, mortality did not exceed $38.9 \%$. At the 5 -days post exposure, the proportion of dead larvae increased significantly, reaching $78.9 \%$ at $0.5 \mathrm{mg}$ a.i. $/ \mathrm{cm}^{2}$. Concerning delayed mortality, chlorantraniliprole killed $91.7 \%$ of the survived larvae at $0.01 \mathrm{mg}$ a.i. $/ \mathrm{cm}^{2}$, while with the increase of the dose mortality reached $100.0 \%\left(0.5 \mathrm{mg}\right.$ a.i. $\left./ \mathrm{cm}^{2}\right)$ (Table 2$)$.

Table 2. Mean delayed \pm SE mortality (\%) of T. confusum adults and larvae exposed on treated concrete with chlorantraniliprole SC at four doses $\left(0.01,0.05,0.1\right.$ and $0.5 \mathrm{mg}$ a.i. $\left./ \mathrm{cm}^{2}\right)$.

\begin{tabular}{lcccc}
\hline Dose & $\mathbf{0 . 0 1} \mathbf{~ m g ~ a . i . / \mathbf { c m } ^ { 2 }}$ & $\mathbf{0 . 0 5} \mathbf{~ m g ~ a . i . / \mathbf { c m } ^ { 2 }}$ & $\mathbf{0 . 1} \mathbf{~ m g ~ a . i .} / \mathbf{c m}^{\mathbf{2}}$ & $\mathbf{0 . 5} \mathbf{~ m g ~ a . i .} / \mathbf{c m}^{\mathbf{2}}$ \\
\hline Life stage & & & & \\
Adults & $86.5 \pm 6.8$ & $93.2 \pm 3.5$ & $95.9 \pm 2.7$ & $97.2 \pm 2.8$ \\
Larvae & $91.7 \pm 4.2$ & $93.5 \pm 4.3$ & $97.2 \pm 2.8$ & $100.0 \pm 0.0$ \\
\hline
\end{tabular}

\section{Discussion}

Chlorantraniliprole is a promising formulation for the control of adults and larvae of T. confusum, when they are exposed on concrete surfaces. It has a unique mode of action, activating the ryanodine receptor in the muscles of insects that causes the release of cellular calcium. The insect stops feeding, its muscles are paralyzed and eventually dies [30-32]. In the present study, chlorantraniliprole killed 70.0 and $78.9 \%$ of the exposed adults and larvae on treated concrete with the highest dose, after 5 days, respectively. On the other hand, 97.2 and $100.0 \%$ of surviving adults and larvae, respectively, died when they were transferred on untreated surfaces, indicating the high delayed effects of this insecticide to the non-toxic areas. This is an important finding considering that the movement of individuals from treated to untreated areas may lead to their colonization by insects [33]. 
In a previous study, two Chlorantraniliprole formulations (WG and SC) have been examined as grain protectant against a wide range of insect pest, including T. confusum adults and larvae [22]. Chlorantraniliprole SC was able to kill a sufficient number of larvae $(94.4 \%$ on maize, $83.3 \%$ on barley and $86.1 \%$ on oat) and adults ( $80.6 \%$ on maize) at the dose of $10 \mathrm{mg}$ chlorantraniliprole $\mathrm{SC} \mathrm{kg}{ }^{-1}$ grain, and reduced the progeny production. Moreover, in the same study, both chlorantraniliprole formulations that tested were very effective for the control of the Mediterranean flour moth, Ephestia kuehniella Zeller (Lepidoptera: Pyralidae), the booklouse, Liposcelis bostrychophila Badonnel (Psocoptera: Liposcelididae), R. dominica and S. oryzae, in six commodities (e.g. barley, maize, oats, whole rice, peeled rice and hard wheat. Similar results were recorded by Boukouvala and Kavallieratos [23], when they examined chlorantraniliprole as maize protectant against the larger grain borer, Prostephanus truncatus (Horn) (Coleoptera: Bostrychidae), at different temperatures.

To conclude, the results of the current study indicate that chlorantraniliprole is an effective management tool against adults and larvae of $T$. confusum on concrete surfaces, with a remarkable delayed effect.

Author Contributions: Designed research, N.G.K.; methodology, N.G.K., M.C.B. and E.P.N.; investigation, N.G.K., M.C.B. and E.P.N.; data curation, M.C.B. and E.P.N.; formal analysis, N.G.K. and M.C.B.; writing-original draft, N.G.K. and M.C.B.; writing-review and editing, N.G.K., M.C.B. and E.P.N.; supervision, N.G.K.; resources, N.G.K.; funding acquisition, N.G.K. All authors have read and agreed to the published version of the manuscript.

Funding: This research was partially funded by the 34.0401 project (Special Account for Research Funds of the Agricultural University of Athens).

Institutional Review Board Statement: Not applicable.

Informed Consent Statement: Not applicable.

Data Availability Statement: Data is contained within the article.

Conflicts of Interest: The authors declare no conflict of interest.

\section{References}

1. Aitken, A.D. Insect Travelers, I: Coleoptera. Technical Bulletin 31; HMSO: London, UK, 1975.

2. Hill, D.S. Pests of Stored Foodstuffs and Their Control; Kluwer Academic Publishers: New York, NY, USA, 2003.

3. Mason, L.J.; McDonough, M. Biology, behavior, and ecology of stored grain and legume insects. In Stored Product Protection; Hagstrum, D.W., Phillips, T.W., Cuperus, G., Eds.; Kansas State University: Manhattan, KS, USA, 2012; pp. 7-20.

4. Hagstrum, D.W.; Klejdysz, T.; Subramanyam, B.H.; Nawrot, J. Atlas of Stored-Product Insects and Mites; AACC International: St. Paul, MN, USA, 2013.

5. Campbell, J. F.; Toews, M. D.; Arthur, F. H.; Arbogast, R. T. Long-term monitoring of Tribolium castaneum in two flour mills: seasonal patterns and impact of fumigation. J. Econ. Entomol 2010, 103, 991-1001

6. .Kavallieratos, N.G.; Athanassiou, C.G.; Hatzikonstantinou, A.N.; Kavallieratou, H.N. Abiotic and biotic factors affect efficacy of chlorfenapyr for control of stored-product insect pests. J. Food Prot. 2011, 74, 1288-1299.

7. Athanassiou, C.G.; Kavallieratos, N.G. Evaluation of spinetoram and spinosad for control of Prostephanus truncatus, Rhyzopertha dominica, Sitophilus oryzae and Tribolium confusum on stored grains under laboratory tests. J. Pest Sci. 2014, 87, 469-483.

8. Kavallieratos, N.G.; Athanassiou, C.G.; Korunic, Z.; Mikeli, N.H. Evaluation of three novel diatomaceous earths against three stored-grain beetle species on wheat and maize. Crop Prot. 2015, 75, 132-138.

9. Lahm, G.P.; Selby, T.P.; Freudenberger, J.H.; Stevenson, T.M.; Myers, B.J.; Seburyamo, G.; Smith, B.K.; Flexner, L.; Clark, C.E.; Cordova, D. Insecticidal anthranilic diamides: A new class of potent ryanodine receptor activators. Bioorg. Med. Chem. Lett. 2005, 15, 4898-4906.

10. Cordova, D.; Benner, E.; Sacher, M.; Rauh, J.; Sopa, J.; Lahm, G.; Selby, T.; Stevenson, T.; Flexner, L.; Gutteridge, S.; et al. Anthranilic diamides: A new class of insecticides with a novel mode of action, ryanodine receptor activation. Pestic. Biochem. Physiol. 2006, 84, 196-214. 
11. Lahm, G.P.; Stevenson, T.M.; Selby, T.P.; Freudenberger, J.H.; Cordova, D.; Flexner, L.; Bellin, C.A.; Dubas, C.M.; Smith, B.K.; Hughes, K.A.; et al. Rynaxypyr ${ }^{\mathrm{TM}}$ : A new insecticidal anthranilic diamide that acts as a potent and selective receptor activator. Bioorg. Med. Chem. Lett. 2007, 17, 6274-6279.

12. Liu, F.; Zhang, X.; Gui, Q. Q.; Xu, Q. J. Sublethal effects of four insecticides on Anagrus nilaparvatae (Hymenoptera: Mymaridae), an important egg parasitoid of the rice planthopper Nilaparvata lugens (Homoptera: Delphacidae). Crop. Prot. 2012, 37, 13-19.

13. Nawaz, M.; Cai, W.; Jing, Z.; Zhou, X.; Mabubu, J.I.; Hua, H. Toxicity and sublethal effects of chlorantraniliprole on the development and fecundity of a non-specific predator, the multicolored Asian lady beetle, Harmonia axyridis (Pallas). Chemosphere 2017, 178, 496-503.

14. Lahm, G.P.; Cordova, D.; Barry, J.D. New and selective ryanodine receptor activators for insect control. Bioorg. Med. Chem. 2009, 17, 4127-4133.

15. Hummel, N.A.; Mészáros, A.; Ring, D.R.; Beuzelin, J.M.; Stout, M.J. Evaluation of seed treatment insecticides for management of the rice water weevil, Lissorhoptrus oryzophilus Kuschel (Coleoptera: Curculionidae), in commercial rice fields in Louisiana. Crop Prot. 2014, 65, 37-42.

16. Plata Rueda, A.; Martínez, L.C.; Costa, N.C.R.; Zanuncio, J.C.; Fernandes, M.E.D.S.; Serrão, J.E.; Guedes, R.N.C.; Fernandes, F.L. Chlorantraniliprole-mediated effects on survival, walking abilities, and respiration in the coffee berry borer, Hypothenemus hampei. Ecotoxicol. Environ. Saf. 2019, 172, 53-58.

17. Teixeira, L.A.F.; Gut, L.J.; Wise, J.C.; Isaacs, R. Lethal and sublethal effects of chlorantraniliprole on three species of Rhagoletis fruit flies (Diptera: Tephritidae). Pest Manag. Sci. 2008, 65, 137-143.

18. Liu, J. L.; Yang, X.; Chen, X.; Wu, J. C. Suppression of fecundity, Nlvg gene expression and vitellin content in Nilaparvata lugens Stål (Hemiptera: Delphacidae) adult females exposed to indoxacarb and chlorantraniliprole. Pestic. Biochem. Physiol. 2012, 104, 206-211.

19. Neoh, K.B.; Hu, J.; Yeoh, B.H.; Lee, C.Y. Toxicity and horizontal transfer of chlorantraniliprole against the Asian subterranean termite Coptotermes gestroi (Wasmann): Effects of donor: Recipient ratio, exposure duration and soil type. Pest Manag. Sci. 2012, $68,749-756$.

20. He, F.; Sun, S.; Tan, H.; Sun, X.; Qin, C.; Ji, S.; Li, X.; Zhang, J.; Jiang, X. Chlorantraniliprole against the black cutworm Agrotis ipsilon (Lepidoptera: Noctuidae): From biochemical/physiological to demographic responses. Sci. Rep. 2019, 9, 1-17.

21. Dale, A.G.; Borden, M.A. Evaluation of reduced-risk insecticides to control chilli thrips (Thysanoptera: Thripidae) and conserve natural enemies on ornamental plants. Fla. Entomol. 2018, 101, 237-243.

22. Kavallieratos, N.G.; Athanassiou, C.G.; Boukouvala, M.C. Insecticidal effect of chlorantraniliprole against major stored-product insect pests in different grain commodities under laboratory tests. Pest Manag. Sci. 2013, 69, 1141-1154, doi:10.1002/ps.3478.

23. Boukouvala, M.C.; Kavallieratos, N.G. Evaluation of Two Formulations of Chlorantraniliprole as Maize Protectants for the Management of Prostephanus truncatus (Horn) (Coleoptera: Bostrychidae). Insects 2021, 12, 194.

24. Saglam, O.; Athanassiou, C.G., Vassilakos, T.N. Comparison of spinetoram, imidacloprid, thiamethoxam and chlorantraniliprole against life stages of Tribolium confusum Jacquelin du Val (Coleoptera: Tenebrionidae) on concrete. Crop Prot. 2013, 53, 85-95.

25. Kavallieratos, N.G.; Athanassiou, C.G.; Boukouvala, M.C. Insecticidal effect of chlorantraniliprole against major stored product insect pests in different grain commodities under laboratory tests. Pest Manag. Sci. 2013, 69, 1141-1154.

26. Kavallieratos, N.G.; Karagianni, E.S.; Papanikolaou, N.E. Life history of Trogoderma granarium Everts (Coleoptera: Dermestidae) on peeled barley, peeled oats and triticale. J. Stored Prod. Res. 2019, 84, 101515.

27. Boukouvala, M.C., Kavallieratos, N.G. Effect of six insecticides on egg hatching and larval mortality of Trogoderma granarium Everts (Coleoptera: Dermestidae). Insects 2020, 11, 263

28. Sall, J.; Lehman, A.; Creighton, L. JMP Start Statistics. A Guide to Statistics and Data Analysis Using JMP and JMP IN Software; Duxbury Press: Belmont, AB, Canada, 2001.

29. SAS Institute Inc. Using JMP 14; SAS Institute Inc.: Cary, NC, USA, 2018.

30. Cordova, D.; Benner, E.; Sacher, M.; Rauh, J.; Sopa, J.; Lahm, G.; Selby, T.; Stevenson, T.; Flexner, L.; Gutteridge, S.; et al. Anthranilic diamides: A new class of insecticides with a novel mode of action, ryanodine receptor activation. Pestic. Biochem. Physiol. 2006, 84, 196-214, doi:10.1016/j.pestbp.2005.07.005.

31. Lahm, G.P.; Stevenson, T.M.; Selby, T.P.; Freudenberger, J.H.; Cordova, D.; Flexner, L.; Bellin, C.A.; Dubas, C.M.; Smith, B.K.; Hughes, K.A.; et al. RynaxypyrTM: A new insecticidal anthranilic diamide that acts as a potent and selective receptor activator. Bioorg. Med. Chem. Lett. 2007, 17, 6274-6279.

32. Sattelle, D.B.; Cordova, D.; Cheek, T.R. Insect ryanodine receptors: Molecular targets for novel pest control chemicals. Invertebr. Neurosci. 2008, 8, 107-119, doi:10.1007/s10158-008-0076-4.

33. Athanassiou, C.G.; Kavallieratos, N.G.; Boukouvala, M.C.; Mavroforos, M.E.; Kontodimas, D.C. Efficacy of alpha-cypermethrin and thiamathoxam against Trogoderma granarium Everts (Coleoptera: Dermestidae) and Tenebrio molitor L. (Coleoptera: Tenebrionidae) on concrete. J. Stored Prod. Res. 2015, 62, 101-107. 